\title{
Stratigraphy, Radiocarbon Dating, and Culture History of Charlie Lake Cave, British Columbia
}

\author{
JONATHAN C. DRIVER, ${ }^{1}$ MARTIN HANDLY,${ }^{2}$ KNUT R. FLADMARK,${ }^{1}$ D. ERLE NELSON,${ }^{1}$ \\ GREGG M. SULLIVAN ${ }^{3}$ and RANDALL PRESTON ${ }^{1}$
}

(Received 23 August 1995; accepted in revised form 27 April 1996)

\begin{abstract}
Three seasons of fieldwork at Charlie Lake Cave, British Columbia, have revealed a sequence of stratified deposits that spans the Late Pleistocene and entire Holocene. Analyses of sediments, radiocarbon dates, faunal remains, and artifacts show that the site was first occupied by people at about 10500 B.P., when local environments were more open than today. By 9500 B.P., boreal forest had moved into the area, and human use of the site was minimal until about 7000 B.P., when a brief occupation of the site probably included a human burial. Use of the site intensified after about 4500 B.P., possibly because the cave became more accessible. The site was used both as a residential base camp and as a more temporary hunting station or lookout.
\end{abstract}

Key words: Paleoindian, Middle Prehistoric, Late Prehistoric, microblade, Holocene, late Pleistocene

RÉSUMÉ. Trois saisons de travaux sur le terrain à la grotte de Charlie Lake (Colombie-Britannique) ont révélé une séquence de dépôts stratifiés qui embrasse le pléistocène tardif et tout l'holocène. Des analyses de sédiments, des datations au radiocarbone, des restes fauniques et des artefacts montrent que l'occupation du site par des individus remonte à environ $10500 \mathrm{BP}$, alors que le milieu local était plus ouvert qu' aujourd'hui. En $9500 \mathrm{BP}$, la forêt boréale avait colonisé la région et l'utilisation du site par les êtres humains a été minime jusqu' à environ $7000 \mathrm{BP}$, alors qu' une occupation brève du site a probablement inclus une inhumation. L'utilisation du site s'est intensifiée après environ $4500 \mathrm{BP}$, peut-être parce que la grotte est devenue plus accessible. Le site a été utilisé à la fois comme camp résidentiel de base et comme poste de chasse et de guet plus temporaire.

Mots clés: paléo-indien, époque préhistorique moyenne, époque préhistorique tardive, microlame, holocène, pléistocène tardif

Traduit pour la revue Arctic par Nésida Loyer.

\section{INTRODUCTION}

There are still areas of northern North America for which cultural sequences are based on only a few sites and rare radiocarbon dates. In these areas, it is important to establish better chronological control before beginning to tackle more complex archaeological research problems. Excavations at Charlie Lake Cave, spread intermittently over a period of nine years, have outlined the prehistory of northeastern British Columbia and of the southern boreal forest fringe of western Canada.

Charlie Lake Cave (HbRf-39) was recorded and tested in 1974 by K.R. Fladmark, who in 1983 directed a full excavation season at the site. Much of the information resulting from that season has been published (Driver, 1988, 1996; Driver and Hobson, 1992; Fladmark, 1996; Fladmark, et al., 1988). Most attention has been paid to two aspects of the site: the long cultural sequence, beginning with a Paleoindian component, and the well-preserved, diverse faunal assemblage, especially that associated with the Paleoindian artifacts.

In 1990 and 1991, J.C. Driver undertook further excavations to obtain larger samples of artifacts and fauna, again focusing special attention on the Paleoindian component. Material from these excavations has formed the topic of an M.A. thesis (Handly, 1993), and will provide the basis for further graduate student work.

\section{SITE LOCATION AND FORMATION}

The Charlie Lake Cave site consists of a number of microtopographic features associated with a cave. The cave is formed in a sandstone escarpment, which appears today as a small sandstone cliff about $2 \mathrm{~m}$ high. The cliff forms a prominent feature on a steep hillside about $25 \mathrm{~m}$ above the north side of Stoddart Creek, which drains Charlie Lake (Fig. 1). Between the floodplain of the creek and the top of the escarpment is a steep slope composed of sandstone boulders derived from the escarpment. These boulders are mantled by locally derived and redeposited glacial and glaciolacustrine sediments and colluvial deposits, on which a modern soil has formed. Above the escarpment the angle of slope declines, and the hillside merges into rolling topography formed by deposits of glacial till, overlain by glaciolacustrine sediments.

\footnotetext{
${ }^{1}$ Department of Archaeology, Simon Fraser University, Burnaby, British Columbia V5A 1S6, Canada

${ }^{2} 653$ Hendry St., Trail, British Columbia V1R 3J4, Canada

${ }^{3}$ General Delivery, Longmire, Washington 98397, U.S.A.

(C) The Arctic Institute of North America
} 


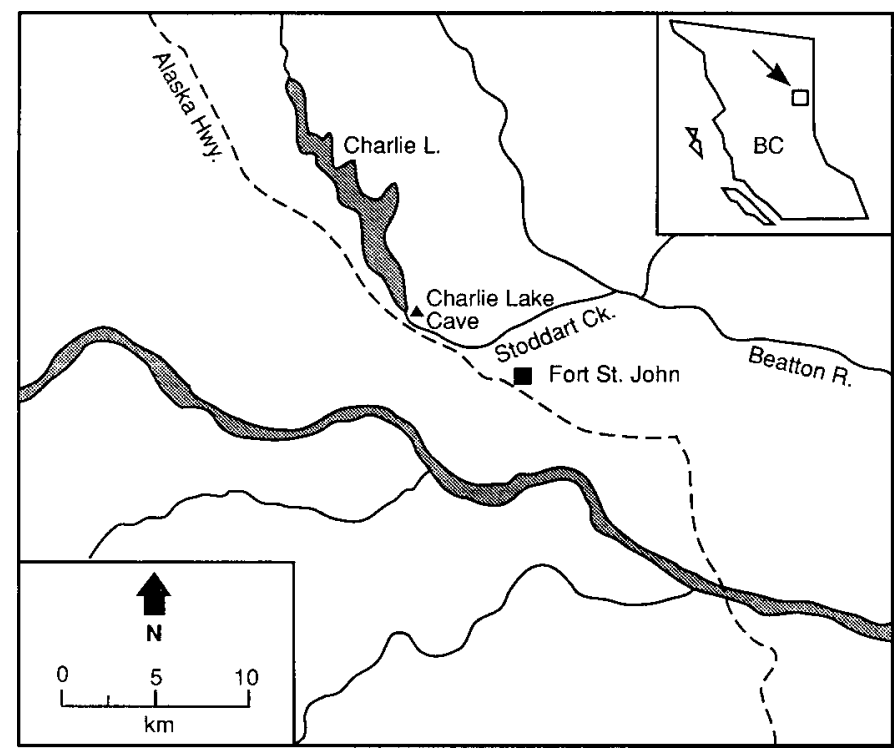

FIG. 1. Location of Charlie Lake Cave. Reprinted from Driver and Hobson (1992) with the permission of the Arctic Institute of North America.

At about 22000 B.P., the Laurentide ice sheet made its final advance across northern Alberta into British Columbia, and covered the site location (Bobrowsky and Rutter, 1992). Dating for the glacial event around Fort St. John is poor, although it must have occurred after 22000 B.P. and before 13000 B.P. It is possible that subglacial water exploited joints and fissures in the sandstone bedrock, resulting in the initial formation of the cave (P. Bobrowsky, pers. comm. 1991). The retreat of Laurentide ice began before 13000 B.P. (Bobrowsky and Rutter, 1992), but ice to the east impeded drainage, and proglacial lakes formed west of the ice margin. Mathews (1980) has demonstrated that a number of glacial lakes inundated the Fort St. John area. Shoreline elevations show that some of these lakes would have covered the Charlie Lake Cave site, and rythmites, which occur on the uplands to the north and east of the site, probably were deposited in one of these lakes. As lake levels went down, the location of the site was exposed. The remnant of a raised beach located on the hillside below the site probably belongs to the Clayhurst stage of Glacial Lake Peace (W. Mathews, pers. comm. 1983). It is not known when the lakes completely drained from the area around Fort St. John, but it probably happened before 10500 B.P., because bison from gravels below the last stage of Lake Peace have been dated to this time (Apland and Harington, 1994).

Once the lake levels had dropped, the glaciolacustrine sediments covering the hillside began to erode, and reexposed the sandstone escarpment. Possibly as a result of freeze and thaw processes operating on joints in the sandstone, a large section of the face of the escarpment was detached from the bedrock. This massive boulder (about 12 $\mathrm{m}$ long, $4 \mathrm{~m}$ wide, and $5 \mathrm{~m}$ high) moved about $3 \mathrm{~m}$ downslope, dropping vertically about $1 \mathrm{~m}$. Surprisingly, the boulder did not topple over, but remained perched on the steep slope. Why this occurred is difficult to determine, but it may be that glacial or glaciolacustrine sediments on the downslope side prevented further movement. This massive rock, marked on Figure 2 as the "parapet," is split down the middle by the same line of weakness in which the cave was formed. The downslope movement of the parapet left a steep-sided gully between it and the bedrock face of the escarpment. The mouth of the cave, assuming that this feature had already been formed by subglacial erosion, would have been about $3 \mathrm{~m}$ above the base of the gully. Any sediments moving subsequently down the upper hillside and over the edge of the escarpment or out of the cave mouth would therefore have been trapped behind the parapet. As a result, the gully has filled with sediments for the past 10500 years. The surface of these sediments is referred to as the "platform" (Fig. 2), because it is today a relatively flat area on a predominantly steep hillside. The floor of the cave retained little sediment for most of the site's history, and it was only when the deposits filling the gully reached the same height as the cave mouth (within the last 1000 years) that sediments could accumulate thinly within the cave itself.

An alternative interpretation of site formation is that the cave was formed only after the detachment of the "parapet" boulder from the escarpment. In this scenario, the cave would have been formed by subaerial weathering along a line of weakness in the sandstone, and the products of such weathering would have been deposited in the gully below the cave.

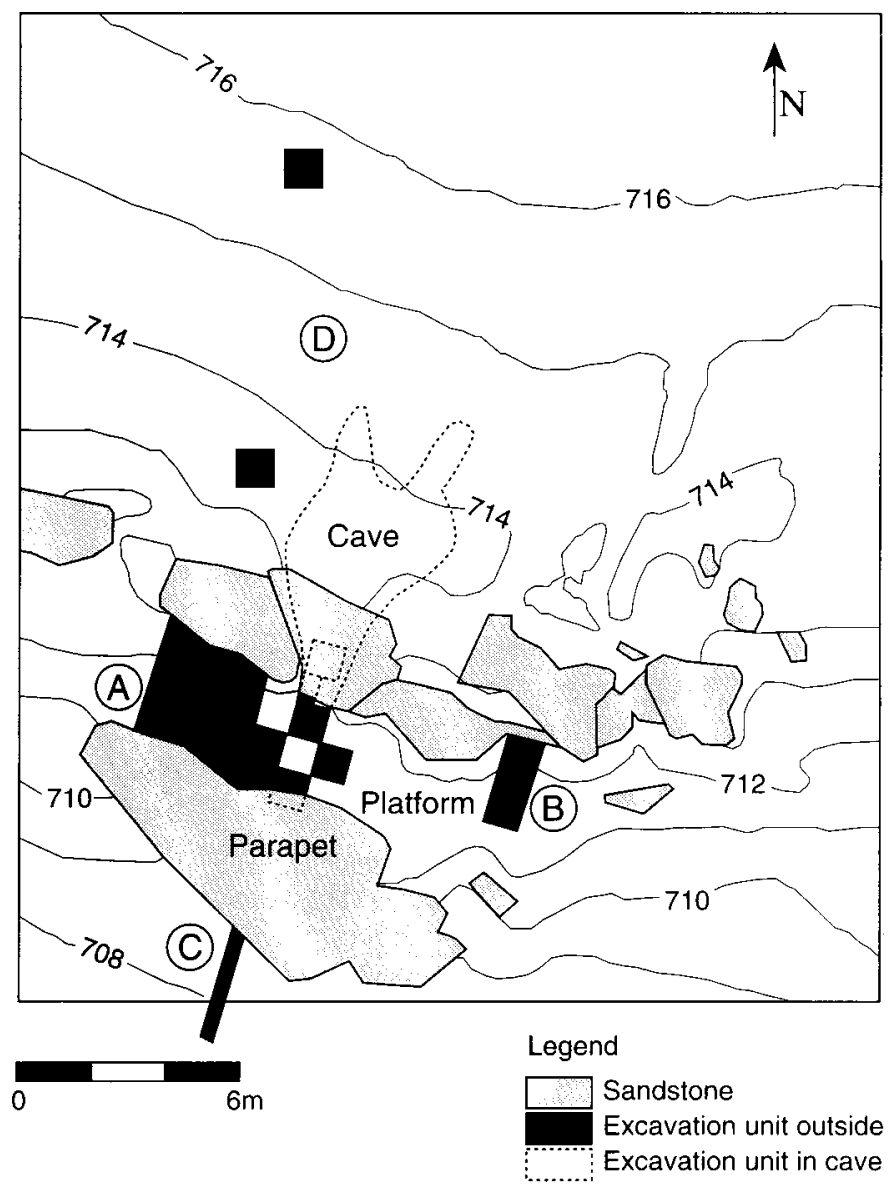

FIG. 2. Location of excavation areas, Charlie Lake Cave. The circled letters indicate excavation blocks. Elevations are in metres above sea level. 
For archaeological purposes, the sediments within the gully are of more importance than the mechanism of gully formation, because they accumulated relatively rapidly (over $4 \mathrm{~m}$ in 10500 years in some places). Most archaeological sites excavated in the boreal forest have very little sediment depth, and this lack of sediment has hampered preservation of cultural and environmental sequences. Although one would expect the cave to contain important cultural materials, test excavations have shown that relatively little cultural material has survived there, perhaps because of frequent use of the cave by twentieth-century children. Many people reported to us that they had dug in the cave as children, and a number claimed to have found stone artifacts there.

\section{EXCAVATION HISTORY}

Archaeological work at the site commenced with two test pits, totalling 1 by $1 \mathrm{~m}$, excavated in 1974 (Fladmark, 1975). These pits did not succeed in penetrating very deep into the gully sediments, and a radiocarbon date suggested a relatively recent age for the cultural and faunal material recovered. Nine years later, a crew directed by Fladmark excavated a series of 1 by $1 \mathrm{~m}$ units, mainly in the platform area (Fladmark et al., 1988). These units established the considerable depth of sediments spanning the entire Holocene period, and defined the major parts of the cultural and stratigraphic sequence. These excavations also recovered the only Paleoindian projectile point from the site. In 1990 and 1991, a crew directed by Driver excavated a block of 1 by $1 \mathrm{~m}$ units in the area that had produced most of the Paleoindian artifacts. In the 1983, 1990 and 1991 seasons, test excavations were also made above and below the site, and geomorphological studies were conducted through a limited number of test units. Handly (1993) has organized the various excavation units into "blocks." Most of the analysis reported in this paper is based on studies undertaken on the largest set of contiguous units, known as "Block A," located on the platform in front of and to the west of the cave entrance (Fig. 2).

Excavation methods in the three main seasons were quite similar, and used the same standardized forms for recording. Distinctive stratigraphic units were identified by colour and texture and referred to as "layers." During excavation, thick layers were divided into arbitrary $10 \mathrm{~cm}$ "levels" contoured to the general slope of deposits.

Excavations were carried out mainly with trowels, and sediments were screened through $3 \mathrm{~mm}$ mesh. The lowest deposits were more difficult to excavate, and a variety of tools (including cold chisels, pry bars, dental picks, pick axes, geological picks, and power tools) were used to expose artifacts and bones. Very little damage was done to the artifacts and bones from the lowest deposits, although the first artifact found in the lowest component (the Paleoindian projectile point) was broken into three pieces. All materials are currently stored at the Department of Archaeology, Simon Fraser University (SFU).

\section{STRATIGRAPHY AND RADIOCARBON DATING}

Layers identified during excavation were grouped into stratigraphic units referred to as "zones," which have been labelled using Roman numerals. With the exception of Zone I, all other zones could be divided into "subzones," identified with lower-case letters. Zones were defined by sediment type, rate of sedimentation, and soil formation processes. Subzones reflect minor variations within zones. Initially, five zones were defined following the 1983 excavations. However, the most recent of these (Zone V) was distinguished only by the presence of historic artifacts, and has been combined with Zone IV, from which it is indistinguishable in colour and texture. The 1990 and 1991 excavations confirmed the presence of four stratigraphic zones. Because the open plan excavation methods allowed for finer stratigraphic resolution, some zones have been divided into more subzones than were originally defined in 1983. It has been possible to correlate the two stratigraphic systems in Block A, where 1983, 1990, and 1991 excavation units are contiguous. In publications that deal exclusively with the 1983 excavations, the 1983 system of zones and subzones has been used. In publications such as this, which deal with material from all seasons, the zonation based on the 1990 and 1991 excavations will be used. Figure 3 illustrates the west stratigraphic profile of the 1990 and 1991 excavations in Block A. Another profile, from the centre of Block $\mathrm{A}$, has been published previously (Fladmark et al., 1988).

Granulometric analysis was conducted on the matrix fraction (particles smaller than $2 \mathrm{~mm}$ in diameter) of sediment samples collected in 1990 and 1991. On the basis of textural parameters of mean grain size and standard deviation (a measure of sorting), all layers were divided into two types, Groups 1 and 2. Group 1 deposits have a very small mean grain size (in the silt range), are poorly sorted, and are composed primarily of glaciolacustrine sediments washed into the gully from upslope. Group 2 sediments have a larger mean grain size (in the sand range), are better sorted than Group 1 deposits, and are composed primarily of sand particles weathered from the local sandstone, with varying amounts of silt and clay contributed from upslope. Group 2 deposits were subdivided into a finer Group 2A (greater amounts of clay and silt) and a coarser Group 2B. The different sediment types are independent of stratigraphic zonation, and reflect the mechanics of sediment formation.

Radiocarbon dates are presented in Table 1. The initial radiocarbon dating (SFU series) was done using the SFU Archaeology Department beta-counting laboratory on samples from the 1983 season. Problems were encountered immediately because the charcoal samples obtained during excavation were very small. These problems were compounded by the chemical fragility of the charcoal. Potential contaminants are normally removed from charcoal by washing with acid $(\mathrm{HCl})$ and then with base $(\mathrm{NaOH})$. However, the base wash removed much of these samples, rendering them even smaller and more difficult to date. This situation was the classic dilemma of all traditional radiocarbon labs: rigorous 


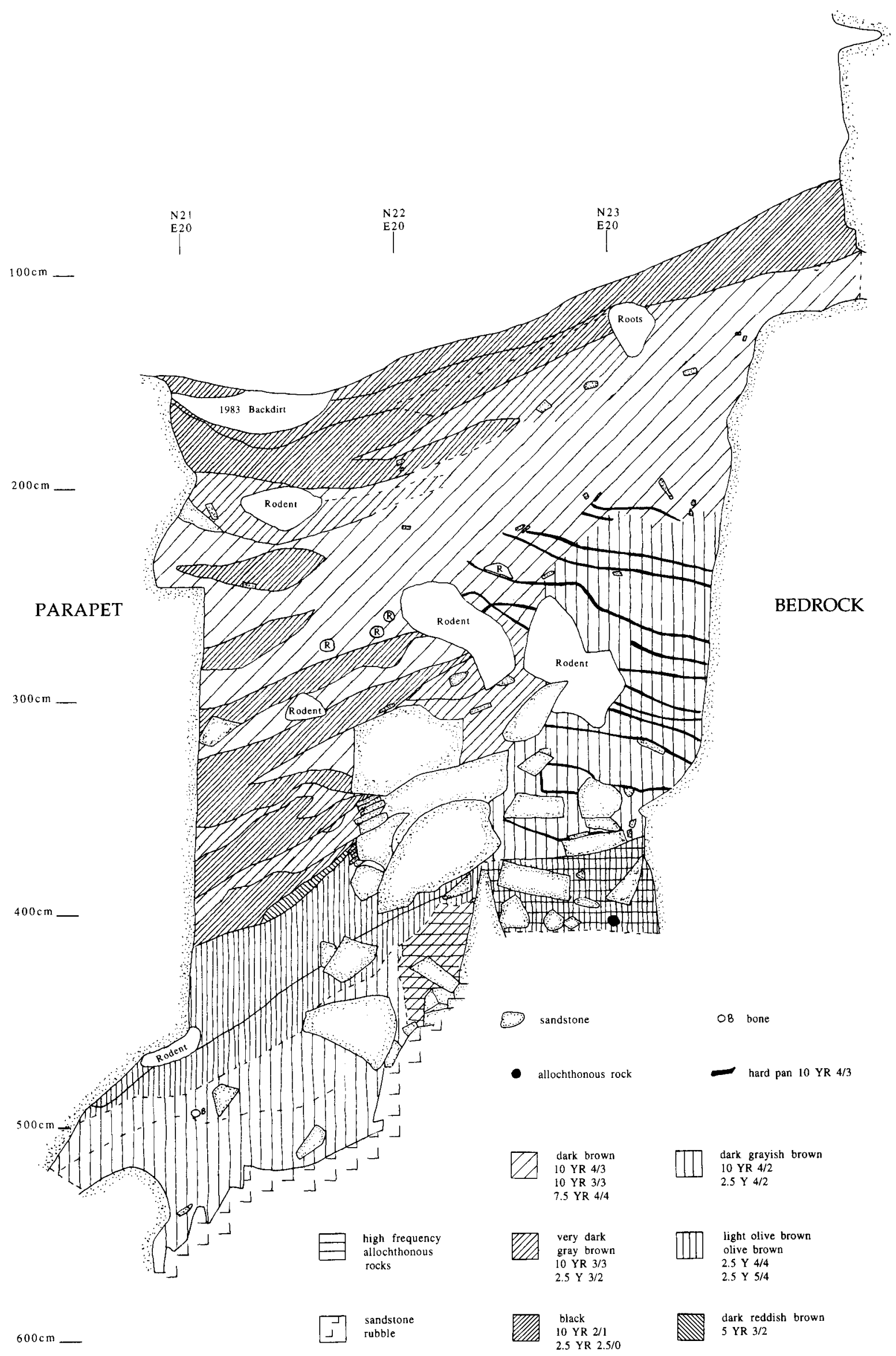

FIG. 3. West stratigraphic profile of 1991 excavations in Block A, Charlie Lake Cave. Depths are given in centimetres below datum. 
TABLE 1. Radiocarbon measurements, Charlie Lake Cave.

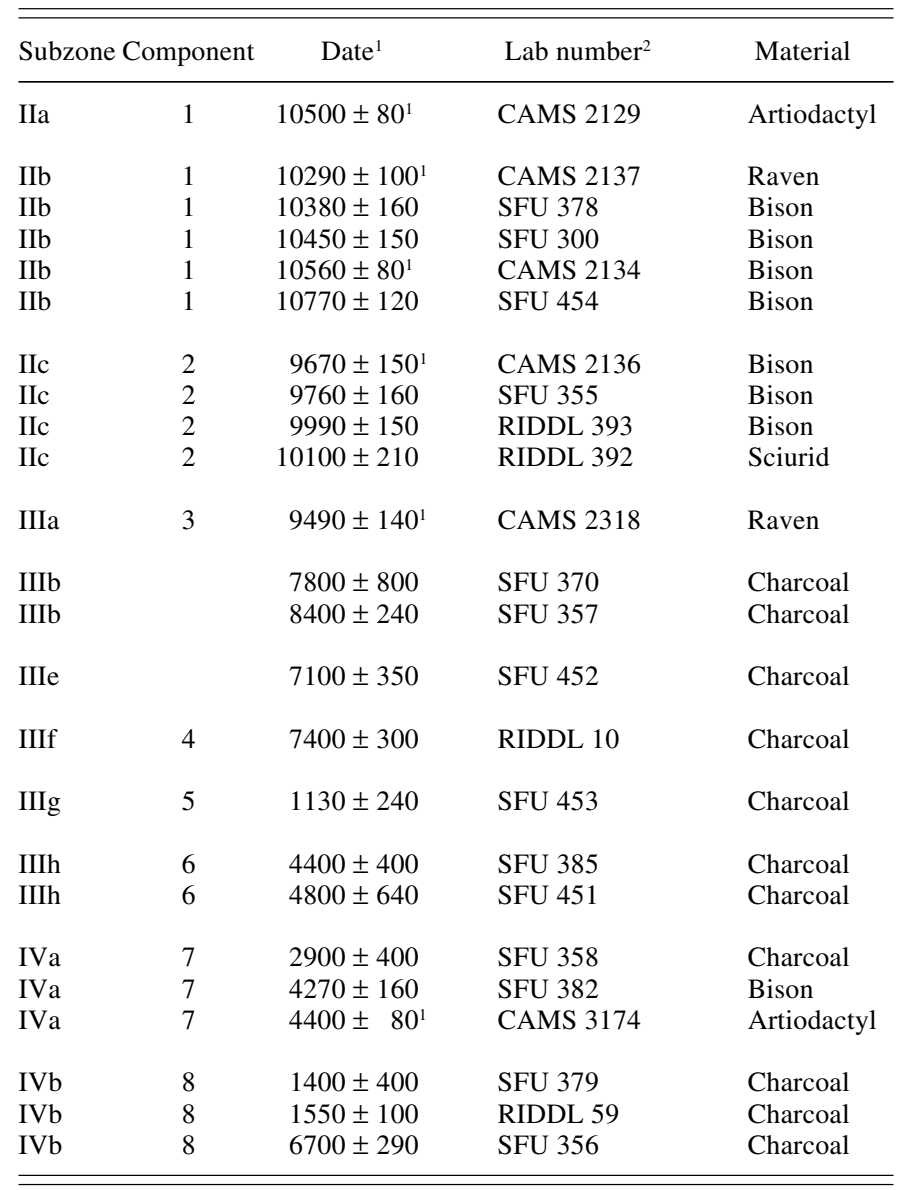

${ }^{1}$ previously unreported date

${ }^{2}$ RIDDL and CAMS dates are by accelerator mass spectrometry; SFU dates are traditional beta counting

treatment may leave little to measure, while insufficient treatment may produce erroneous results. In this case, as in many others, a balanced approach was attempted, and that is reflected in the large uncertainties associated with the SFU charcoal dates. These difficulties were exacerbated by the realization that two samples (SFU 356 and SFU 453) had probably been mixed up, either in the field or in the lab.

Shortly afterwards, accelerator mass spectrometry (AMS) measurement capabilities became available at SFU. This method removed the problems due to sample size, and a suite of AMS dates (the Radio Isotope Direct Detection Laboratory [RIDDL] series) was taken on further 1983 samples to test the traditional measurements. Later, these early AMS measurements were supplemented by further dates from another AMS lab (the Center for Accelerator Mass Spectrometry [CAMS] series) taken on materials excavated in 1990 and 1991.

A plot of radiocarbon age as a function of relative depth is presented in Figure 4. The depth of the radiocarbon sample is expressed as a percentage of the total depth of the quadrant of the excavation unit in which the date occurs. For example, a sample found $3 \mathrm{~m}$ deep in an excavation unit containing $4 \mathrm{~m}$ of deposit would be given a depth of $75 \%$. This calculation has been used because the total depth of sediment varies across the site, and the stratigraphy dips quite steeply across the gully (see Fig. 3). With the exception of two measures (SFU 356 and 453), all others form an ordered progression, into which the two exceptions would fit if their sample numbers were switched. Unfortunately, we cannot retest this possible mistake, as both samples were entirely consumed in the traditional measurement process. Even so, we believe the AMS dates remove any substantial ambiguity, and that the data in hand provide a reliable chronological framework for the natural and human history of the site.

When the boulder that now forms the "parapet" moved downslope shortly before 10500 B.P., it created Zone I, which consists of a layer of crushed in situ sandstone and a mass of overlying boulders. The crushed sandstone was presumably created by the weight of the boulder moving downslope. Smaller boulders seem to have broken away from the base of the parapet as it detached from the bedrock, and now form a confused jumble of rock, lying at a fairly steep angle in the bottom of the gully. Most of these smaller boulders are found on the north side of the gully. This may indicate that the boulder first detached and moved a short distance, and then moved again. Alternatively, the "parapet" may have moved only once, depositing large boulders near the point of detachment. Those boulders vary in size; the largest, about $1 \mathrm{~m}$ in height, stands vertically in the northwest corner of Block A. All boulders in Zone I are very resistant to mechanical fracturing, unlike most other sandstone boulders encountered higher in the excavation, which could be broken quite easily by cold chisel and hammer. The unweathered nature of the Zone I boulders suggests that they were not exposed to weathering before deposition (as would be expected if they had been formed during the detachment of the parapet and then protected from further weathering). Because of the difficulty in breaking up these rocks, they were removed only along a $1 \mathrm{~m}$ wide strip between the bedrock and the parapet.

Immediately after the initial movement of the "parapet" and the formation of the gully, sediments began to move downslope from the hillside above the site. These sediments formed a layer up to $1 \mathrm{~m}$ thick across the bottom of the gully; they are thickest to the south, where they comprise Zone II. Although no bedding structures were visible in these sediments, differences in texture and compactness were observed during excavation, allowing four subzones to be defined. The matrix of Zone II sediments belongs primarily to the Group 1 type, which suggests that rapid redeposition of glaciolacustrine sediments from upslope was the primary source of these deposits, rather than erosion of the local sandstone. These sediments were transported very rapidly into the gully at first, probably by mass wasting, and subsequently by slope wash until the sediments above the site became more stable. In the upper subzones of Zone II, the matrix becomes coarser (Group 2 sediments), indicating reduced input from upslope, slower overall rates of deposition, and a greater contribution from weathering of local sandstone. Zone II dates from about 10500 to 9500 B.P. As can be seen from Table 1, there is a fairly good separation of 
radiocarbon dates from the lower part of Zone II (Subzones IIa and IIb) and the upper part of Zone II (Subzone IIc); the dividing line occurs at about 10000 B.P. This division, also recognized in the 1983 excavations, corresponds to a shift in fauna, which suggests an environmental change (Driver, 1988). The lack of organic matter in Zone II supports the conclusion that deposition was too rapid and continuous to allow pedogenesis to occur.

Zones III and IV represent a shift toward the general depositional processes that occur at the site today. Zone III dates from about 9500 to 4500 B.P., and sand particles from in situ weathering of the local sandstone dominate the sediments. Transport of finer particles of glaciolacustrine deposits from upslope decreased during its deposition, and so did the sedimentation rate. In the lower subzones (IIIb-IIIe), Group 2B sediments dominate; these coarser sediments represent a reduction in slope wash. Later subzones are dominated by $2 \mathrm{~A}$ sediments, which represent a renewed contribution of upslope sediments. This change might coincide with the "Hypsithermal," a period of decreased precipitation recognized in some paleoenvironmental reconstructions for the southern boreal forest (LichtiFederovich, 1970). Slower rates of deposition allowed pedogenesis to occur at various times, and resulted in a greater organic matter content for Zone III. Horizons with higher proportions of organic material do not extend across the gully because of postdepositional leaching by groundwater percolating through sediments on the north side of the gully. This leaching also lowered the $\mathrm{pH}$ in more northern sediments, resulting in poorer survival of bone.

Zone IV differs from Zone III mainly in the decreased slope of deposits and the presence of pedogenic layers extending across the gully. Texture continues to be dominated by sand, but the amount of silt or clay particles contributed by slope wash seems to vary through the profile. Organic matter content is higher, and pedogenic horizons are thicker. This may be because more sunlight created denser vegetation as the deposits built higher in the gully and the slope of the sediments decreased. Organic material was also added by packrats, whose nests and droppings are common in more recent layers. Although there appears to be an increased sedimentation rate (Fig. 4), the lower bulk density of sediments due to greater amounts of organic matter may be responsible for this appearance.

The stratigraphic integrity of the site is suggested by the fairly good relationship between radiocarbon age and depth of sample. In 1990 and 1991, the open area excavation methods allowed for easy identification of rodent burrows. Generally, rodent holes were rare, narrow, and short. The only exception to this is a complex of tunnels containing woodchuck (Marmota monax) bones excavated from the northwest corner of the main excavation area in 1990. The size of this disturbance can be estimated from the rodent holes shown in Figure 3. The animals burrowed laterally into the deposits from the west, affecting about a square metre of deposits. In Zone II, numerous ground squirrel (Spermophilus sp.) bones have been found. AMS dating of one of these bones

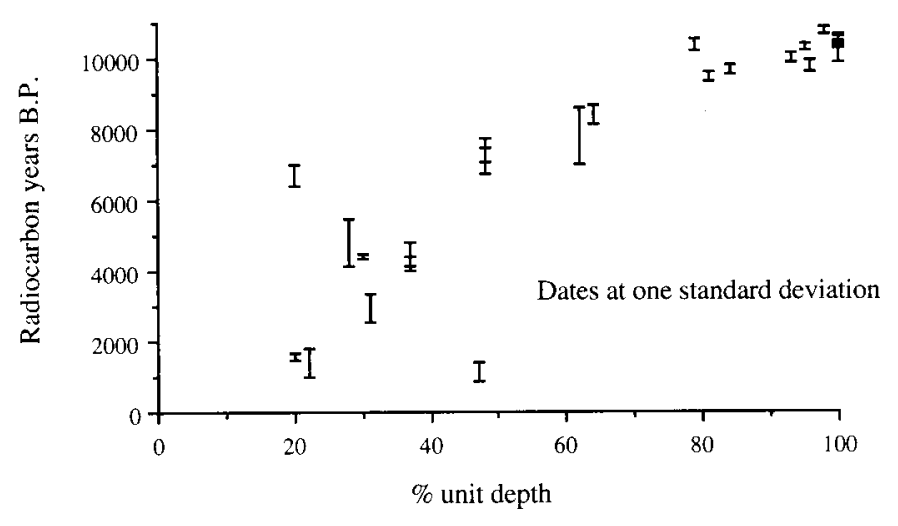

FIG. 4. Radiocarbon dates plotted against depth of sample.

demonstrates its contemporaneity with the sediments in which it was found (Driver, 1988). There has been little disturbance by roots at the site, and there is no evidence that large tree roots or tree falls have disturbed the deposits.

In summary, sediments have been deposited at varying rates in the gully since 10500 B.P. For the first 1000 years, deposition was relatively rapid, probably because glaciolacustrine deposits were being eroded rapidly after the recession of Glacial Lake Peace. After 9500 B.P., deposition rates slowed down, and soils formed in the gully. Pedogenesis was interrupted frequently by continual deposition, which buried old soils and formed new surfaces for further soil formation. The organic content of sediments has been affected by postdepositional leaching by groundwater on the northern side of the gully. Disturbance by rodent burrowing has been a factor in the formation of the deposits, but seems to have been minor and limited in extent.

\section{CULTURAL COMPONENTS}

We have defined ten cultural components, on the basis of stratigraphy rather than the nature of the artifacts. Generally, artifacts found within the deposits of a particular subzone have been defined as a component, and we have not attempted to either separate different occupations within a subzone or to lump occupations from different subzones. This strategy was chosen because most subzones contain relatively few artifacts, and few of these artifacts clearly display an intentional style in their formal properties. The majority of artifacts are chipped stone (mainly debitage), but there are a few ground stone and bone or antler pieces. This discussion emphasizes artifacts that can be compared stylistically with other assemblages, and is concerned mainly with culture history. A detailed lithic analysis has already been reported, and cultural components have been grouped into Early, Middle, and Late Prehistoric periods (Handly, 1993).

\section{Early Prehistoric}

Component 1 occurs mainly within subzone IIb, and dates to approximately 10500 B.P. The calculation is based on an 
average of six dates (Table 1). This component is associated with butchered bison bone of an extinct species. In 1983, four formed artifacts were recovered (Fladmark et al., 1988). In 1991, more artifacts were added to the inventory. The complete basally thinned projectile point (Fig. 5a) shares features with similar points from surface sites in the Peace River and central and southern Alberta. No other dated sites in Canada contain this type of point. We exclude Sibbald Creek (EgPr2) from consideration, because the dated charcoal from that site was not collected solely from the levels that produced basally thinned points (Gryba, 1983). From Montana, Davis and Greiser (1992) reported what appears to be a partially finished specimen with basal characteristics similar to those of the Charlie Lake specimen. This Montana artifact is associated with a date on scattered charcoal of 11000 B.P., which is likely to be somewhat older than the date when the point was deposited. Frison (1991) described projectile points from the Goshen Complex that are basally thinned, but not fluted. These are dated around 11000 B.P. at the Mill Iron site in Montana. Although the flaking pattern on the blade is different, the treatment of the base appears similar to that of the Charlie Lake specimen. We believe that the Charlie Lake point is probably derived from a late fluted point tradition, such as those seen in Montana. However, because of the scarcity of excavated specimens, the Charlie Lake point remains in unfortunate isolation as the only well-dated representative of the late fluted point tradition in western Canada.

Other artifacts have less information to provide on culture history but do suggest a limited range of activities for Component 1 . Most notable is a series of large quartzite artifacts, which range from a barely retouched cobble to a biface and a well-made uniface (Fig. 6). Although Handly (1993) has classified these formally in a variety of ways-as cores, retouched flakes, bifaces, etc.- - they have some common features that suggest a possible common function. They are relatively heavy and have strong, roughly shaped edges. They are all approximately $20 \mathrm{~cm}$ long. On many specimens, there is evidence for heavy use of the edges, such as battering and dulling. No debitage from the quartzite artifacts has been recovered, suggesting that they were made elsewhere, transported to the site, used, and discarded. We tentatively identify these as an assemblage associated with heavy butchering. That they were abandoned in the midst of broken bison bones suggests that they were connected in some way with butchering, although it is of course possible that the final association of bones and artifacts was the result of refuse disposal methods rather than a functional relationship.

Other chipped stone artifacts include some retouched flakes (Fig. 5b, c) and a small quantity of debitage (Table 2). The assemblage conforms to our expectations for kill-site assemblages, in that artifact diversity is low, debitage is rare, and the artifacts appear on morphological grounds to have functioned in hunting and butchering. The only exception to this is a small fragment of local schist which has been perforated biconically (Fig. 5e). This "bead" (Fladmark et al., 1988) was presumably for decorative purposes, although its rough outline suggests that it may never have been finished.

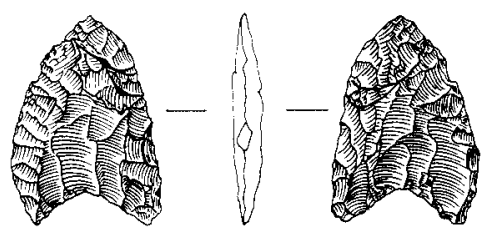

a

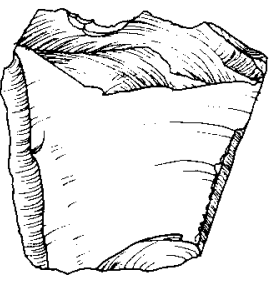

C

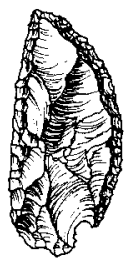

d

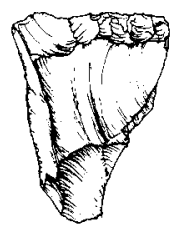

b

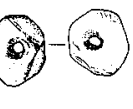

e

cms

FIG. 5. Artifacts from Component 1 (a, b, c, e) and Component 2 (d).

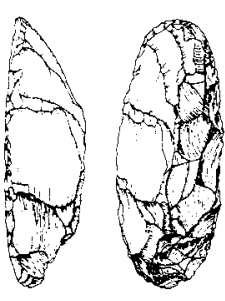

a

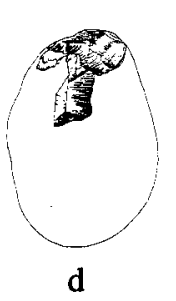

d

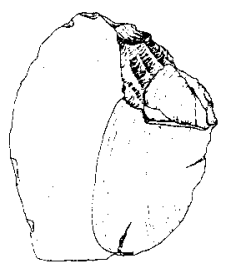

b
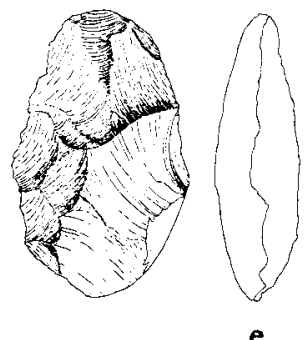

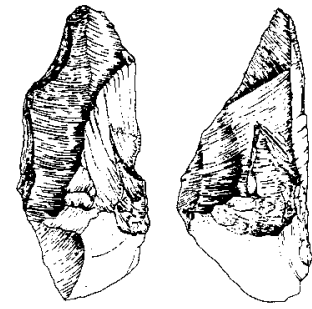

c
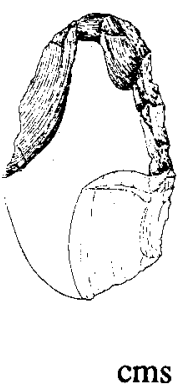

FIG. 6. Large quartzite artifacts, Components 1 and 2.

The bison bones recovered in association with Component 1 are mainly lower leg bones, which might well have been left behind at a kill because of their relatively low meat yield.

Associated with the bison bones and artifacts were numerous small rodent and bird bones. One notable find in 1991 was a large part of a raven (Corvus corax) skeleton (one of whose bones provides one of the later dates for Component 1). A small section of tracheal rings was also preserved, testifying to the extremely good preservation conditions of Zone II deposits. Articulated sets of bones, as well as the tracheal 
rings, show that the bird was deposited as a relatively complete carcass. Whether or not humans were involved in the death or deposition of the bird is difficult to say.

Component 1 shows that the first human inhabitants of the postglacial landscape were probably big-game hunters specializing in bison. As described elsewhere (Driver, 1988, 1996), this early landscape was open, with relatively little forest. The similarities to artifacts found elsewhere indicate that possibly people first entered this region from the southeast, as part of a bison-hunting population that expanded north and west as the glacial and lacustrine barriers disappeared.

Component 2 from Subzone IIc contains no distinctive artifact styles, and the total asssemblage is smaller and contains fewer stone tools than Component 1. It is associated with bison bone, and may represent a kill similar to that seen in Component 1. It dates to 9850 B.P. (average of four dates).

Component 3, in Subzone IIIa, dates to about 9500 B.P. and produced the most unexpected find of the 1991 excavation season. A microblade core was found in association with a considerable portion of another raven skeleton (Fig. 7) lying against the southern wall of the gully. The exact position and orientation of the microblade core are unknown, because the senior author was so intent on excavating the articulated bird skeleton that he ignored the microblade core until it was dislodged. However, it was lying near the feet of the raven. The raven skeleton consists of both legs and both wings, with bones from all four limbs lying in roughly anatomical position. Most of the vertebrae are missing, as are the sternum, ribs, pelvis, and head. Bones of the pectoral girdle (coracoid, scapula, and furculum) are present. It is possible that the missing bones were removed by scavengers, but this seems unlikely, because the rest of the skeleton was not scattered. A more plausible explanation is that the relatively fragile axial elements were destroyed by weathering or chemical activity. This interpretation is supported by the presence of weathered vertebrae, sternum fragments, and cranial fragments. The limb bones also show evidence of weathering and chemical erosion of their surfaces, and numerous postdepositional breaks have occurred on the long bones.

The microblade core (Fig. 8) presents some problems of interpretation. It is made from a small piece of tabular greyblue chert. The two sides of the core (Fig. 8b, e) are formed by the natural bedding planes of the rock. The base (Fig. 8c) has been steeply and unifacially retouched, and may have been used as an endscraper. It is also possible that the retouch was to create a keel for the microblade core, as there is some crushing along the retouched edge, which might be a response to force applied when microblades were detached. The striking platform (Fig. 8a) is formed by what looks like a heat fracture, although there are traces of platform preparation scars at the end from which the microblades were struck, and there is some lateral crushing along one side of the platform, similar to platform damage observable on some Alaskan wedge-shaped cores. One end of the core is unmodified (Fig. 8f). The other end (Fig. 8d) displays traces of six microblade removals. The first three presumably ran the full

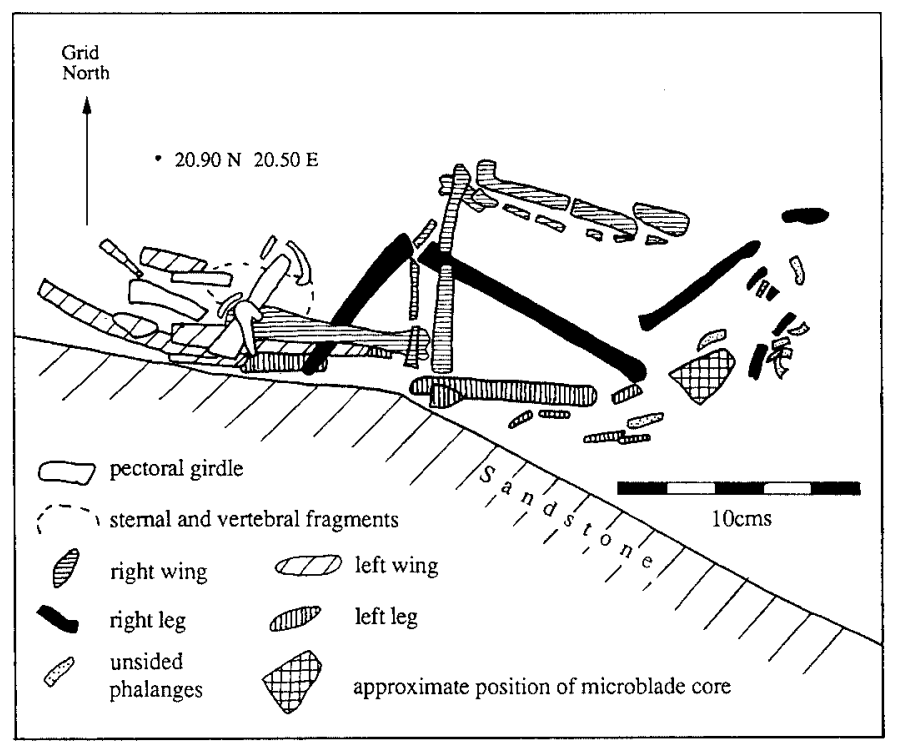

FIG. 7. Articulated raven skeleton and associated artifact, Component 3.

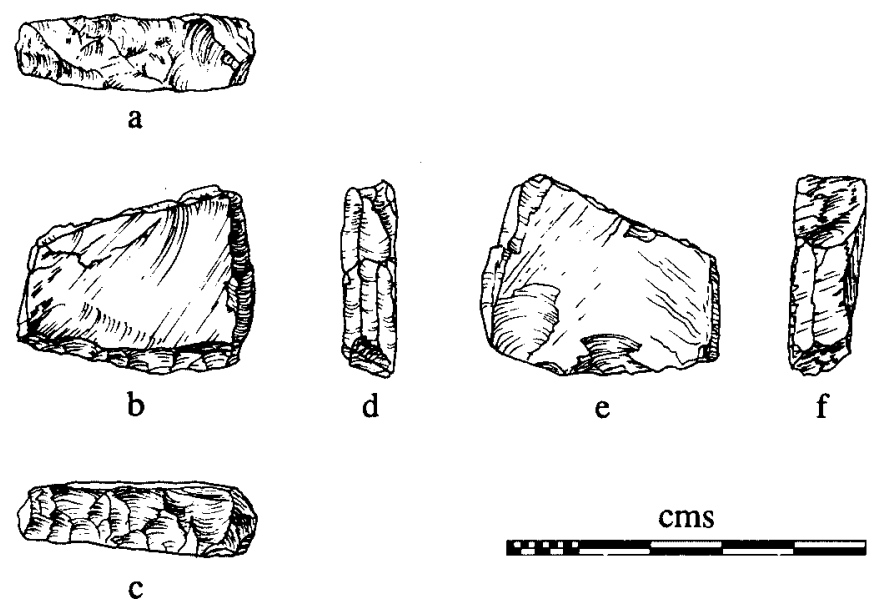

FIG. 8. Microblade core, Component 3.

depth of the core, to produce blades about $2 \mathrm{~cm}$ long. The last three all terminated halfway down the face of the core, and would have produced very small blades. Without further reshaping, the core would not have produced any more useful microblades, and it could be classified as exhausted.

In terms of overall size and shape, the core resembles the wedge-shaped cores of Alaska more than the conical or irregular microblade cores of later Holocene sites in northern British Columbia and Alberta. The Charlie Lake specimen is not a typical wedge-shaped core, because it lacks the sharp keel seen on most specimens. However, the platform preparation is similar, as is the removal of multiple microblades from a single face. Technologically, the Charlie Lake specimen is different from many Alaska specimens because it is not prepared bifacially. However, if one presumes that the bifacial preparation was normally undertaken to shape the core blank, this would not have been necessary with the tabular raw material from which the Charlie Lake core was made. Some Alaskan cores lack bifacial preparation as well. 
A number of studies have shown that wedge-shaped cores occurred early in the Alaska sequence, even though they may have persisted until late Holocene times (Mobley, 1991). For example, Powers and Hoffecker (1989) showed that wedgeshaped microblade cores occurred in the Nenana Valley, Alaska, by about 10500 B.P. Wedge-shaped cores have also been found nearer Charlie Lake Cave than the Alaska specimens, in Alberta. These include a recently reported specimen from Fort Vermilion, about $600 \mathrm{~km}$ downstream from Fort St. John on the Peace River (Pyszczyk, 1991), and a larger assemblage from the 4000 B.P. Bezya site in northeastern Alberta (LeBlanc and Ives, 1986). Microblades have also been found in southern Alberta at the High River site, in association with early Holocene Cody Complex artifacts (Sanger, 1968); the cores from that site recovered subsequent to Sanger's investigation remain unillustrated, but are reported as wedge-shaped (LeBlanc and Ives, 1986). Fedje et al. (1995: Fig. 11e) illustrated a broken biface, which may have been used as a microblade core, at the Vermilion Lakes site in Banff National Park, Alberta. This artifact is associated with radiocarbon dates of about 9900 B.P. Clark (1992) has reviewed the distribution of wedge-shaped cores outside of Alaska. The Charlie Lake and Vermilion Lakes examples appear to be the among the most southerly, and are the oldest examples known from Canada. Alaskan specimens are older and much more common.

\section{Middle Prehistoric}

Component 4, in Subzone IIIf, dates to about 7000 B.P. This component does not contain any temporally diagnostic tools, although Handly (1993) considers that a complete biface is similar to bifaces from the Taye Lake Phase in southwest Yukon (Workman, 1978). A piece of obsidian debitage has been sourced to Mt. Edziza, about $600 \mathrm{~km}$ northwest of the site. A fragmentary human mandible is also associated with this component. There is no evidence for deliberate burial, and we conjecture that it was displaced from a burial upslope, possibly in the cave.

Component 5 in Subzone IIIg has no acceptable associated radiocarbon dates, but must lie somewhere between 7000 and 5000 B.P. The projectile point recovered (Fig. 9a) has shallow side notches and basal thinning. Side-notched points were widespread in western North America at this time, and nothing about this specimen allows us to compare it specifically to any more restricted region. A similar specimen was recovered from the nearby Farrell Creek site, dated at about 4400 B.P. (Spurling, 1980: Fig. 34g). Outside of the Peace River area, similar specimens have been found in the Acasta Lake Phase in the central District of Mackenzie (Noble, 1971), in the Pointed Mountain Complex of the western District of Mackenzie (Millar, 1968; Morrison, 1987), and in the Taye Lake Phase of southern Yukon (Workman, 1978). Dates range from 7000 B.P. to 1600 B.P.

Component 6 in Subzone IIIh is well-dated to about 4500 B.P. As well as evidence for a range of lithic reduction activities, artifacts include a well-made side-notched

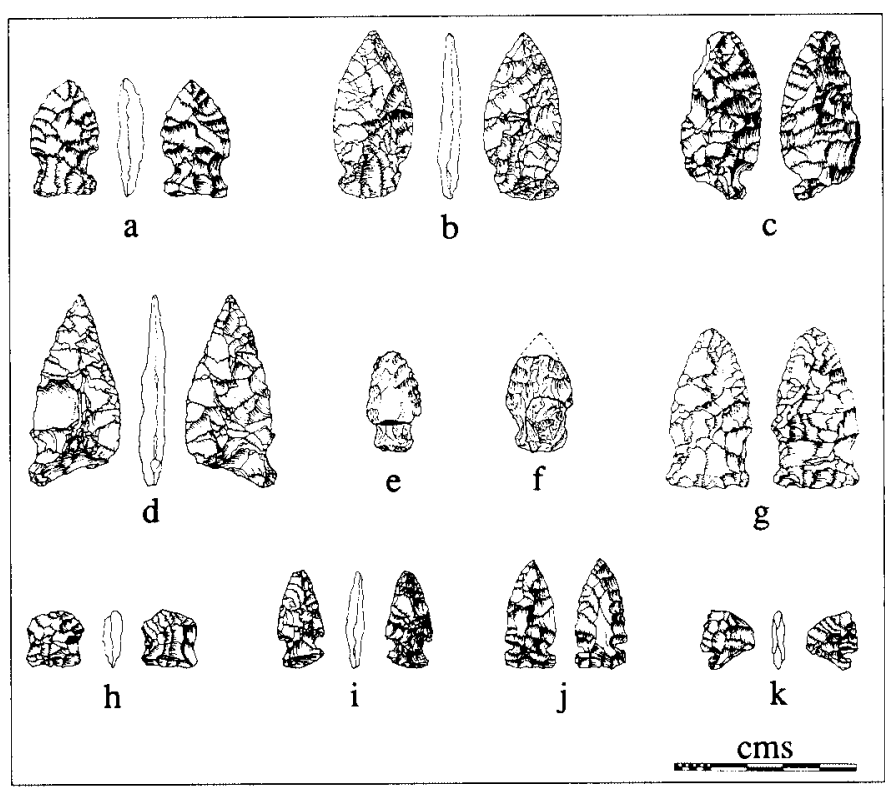

FIG. 9. Projectile points from Components 5 (a), 6 (b), 7 (c, d), 8 (e, f), 9, and $10(\mathrm{~g}-\mathrm{k})$.

projectile point (Fig. 9b) and a single microblade. A hearth was located to the west of the cave mouth. Sites in the region with similar projectile points include HbRb-17 (Spurling, 1980) and the Karpinsky site (Bryan and Conaty, 1975), although neither has produced radiocarbon dates associated with the projectile points. At Tezli, in north central British Columbia, a similar artifact was dated between 3300 and 3900 B.P. (Donahue, 1975).

Component 7 in subzone IVa has three examples of sidenotched, concave-based points (Fig. 9c, d), and a fragment of a small corner-notched point, dating to about 4300 B.P. The larger points have similarities to the Oxbow type of the northern plains and parkland region. Spurling and Ball (1981) suggested that these artifact types entered the Peace River area at a later date, proposing that a general decrease in the age of such artifacts is correlated with more northern latitudes. According to their data, Oxbow-like points in the Peace River should fall in the 3000 to 2500 B.P. range. The Charlie Lake Cave dates appear to refute this hypothesis.

Comparable specimens have been recovered from Farrell Creek (Spurling, 1980), the Karpinsky site (Bryan and Conaty, 1975), the Smoky site in north central Alberta (Brink and Dawe, 1986), and the Ski Hill site in northwestern Alberta (Thomson, 1973). However, all radiocarbon dates postdate 2000 B.P. Also, projectile points with a similar configuration are reported from the early part of the Shuswap horizon to the south and west of Charlie Lake Cave on the interior plateau of British Columbia, dating from about 4000 to 3000 B.P. (Richards and Rousseau, 1987).

In north central British Columbia, Donahue (1975) describes similar projectile points at Tezli dated around 1900 B.P. In northern British Columbia and southwest Yukon, similar projectile points have been found in Taye Lake Phase and Aishihik Phase sites (MacNeish, 1960; Workman, 1978). The early dates for Taye Lake Phase fit the Charlie Lake 
dates. In central District of Mackenzie, Noble (1971) defined an Oxbow complex dated 4500 to 3500 B.P., and the Fish Lake complex in western District of Mackenzie contains similar artifacts dated 3000 to 2500 B.P. (Millar, 1968).

\section{Late Prehistoric}

Component 8 in Subzone IVb probably dates to about 1500 B.P. It contains two small, apparently reworked projectile points with shallow side notches and convex bases (Fig. 9e, f). Two hearths and a cache of flakes were associated with Component 8 . The projectile points can be compared with specimens from the Karpinsky site (Bryan and Conaty, 1975) dated at 1100 B.P. More distant comparisons include specimens from the Timber Point complex (2400 to 2700 B.P.) of the District of Mackenzie (Noble, 1971).

Components 9 and 10 occur in Subzone IVc and postdate 1500 B.P. Three point types have been recovered. Two large specimens with shallow side notches and flat bases (Fig. 9g, h) are similar to a specimen from Farrell Creek dated to 1600 B.P. (Spurling, 1980), and to another from the Ski Hill site (Thomson, 1973). These points are similar to Taltheilei Tradition specimens from 1900 to 300 B.P. (Noble, 1971). Similar specimens have also been found in northern British Columbia (MacNeish, 1960), in the western District of Mackenzie in the Mackenzie Complex (Millar, 1968), and in the Pointed Mountain Complex (Morrison, 1987).

Two small side-notched points (Fig. 9i, j) and one small corner-notched point (Fig. 9k) are similar to a range of arrowhead styles from many areas of northwestern North America dating to within the last 1000 years.

Much of the debitage from Component 9 occurred in an oval depression in front of the cave mouth. Not enough of this feature was excavated to determine if it was part of a structure. It was at least $3 \mathrm{~m}$ long, $2 \mathrm{~m}$ wide and about $30 \mathrm{~cm}$ deep.

\section{DEBITAGE ANALYSIS}

Handly (1993) provides a detailed study of the debitage from the site, which we summarize here. Chipped stone artifacts were divided into cores, unformed tools, formed tools, and debitage (Table 2). Debitage was analyzed using a combination of mass analysis (Ahler, 1989; Baumler and Downum, 1989) and individual flake analysis (Wilmsen, 1970; Rozen and Sullivan, 1989). Mass analysis is concerned with the overall size distribution of the debitage assemblage, while analysis of individual attributes examines variability within the assemblage. All debitage was described using the following attributes: raw material, size, weight, initiation face (striking platform) modification, interior surface lipping, eraillure scarring, exterior scar count, and cortex cover. Justification for these attributes is described elsewhere (Handly, 1993). Raw material selection may provide information about mobility across the landscape. The other attributes are expected to relate to the technology of stone tool production, specifically to the type of flaking being done and
TABLE 2. Summary of lithic data by component, Charlie Lake Cave.

\begin{tabular}{crrrrr}
\hline \hline Component & Debitage & Unformed & Formed & Cores & Total \\
\hline 1 & 8 & 8 & 1 & 2 & 19 \\
2 & 28 & 3 & 0 & 1 & 32 \\
3 & 160 & 1 & 0 & 1 & 162 \\
4 & 68 & 8 & 1 & 2 & 79 \\
5 & 121 & 11 & 4 & 7 & 143 \\
6 & 96 & 9 & 2 & 1 & 108 \\
7 & 33 & 6 & 5 & 2 & 46 \\
8 & 216 & 17 & 8 & 1 & 242 \\
9 & 361 & 6 & 6 & 1 & 374 \\
10 & 132 & 4 & 6 & 0 & 142 \\
Total & 1223 & 73 & 33 & 18 & 1347 \\
\hline \hline
\end{tabular}

the stage of reduction reached during the preparation of stone tools.

Analysis of raw material showed that virtually all chipped stone specimens were made on chert. Although various different types of chert were defined on the basis of colour and inclusions, the significance of these cannot be determined, as no lithic sources are known, apart from cobbles and pebbles in local gravels. In the Early Prehistoric assemblages, the most common raw material is a vitreous grey chert. In the Middle Prehistoric period, vitreous black chert is dominant. A vitreous mottled chert is most common in Late Prehistoric components.

Component 1 contains relatively little debitage. The small sample displays high cortical frequencies, unprepared platforms, and low exterior scar counts, indicating early-stage lithic reduction.

Component 2 debitage is characterized by small size, low cortical counts, low frequencies of interior surface lipping, and moderate values for exterior scar counts. A variety of reduction strategies may be represented, but the sample is too small to be certain.

The majority of debitage from Component 3 was recovered from an area of about one square meter. Debitage is small, with more than $90 \%$ of the sample weighing less than $0.1 \mathrm{~g}$. This suggests late-stage lithic production, as do crushing, facetting, and grinding of platforms, higher frequencies of lipping, low frequency of eraillure scars, and high counts of exterior flake scars. The majority of debitage was probably produced during biface production or maintenance. The raw material types indicate that at least two bifaces were prepared. The presence of a microblade core and maintainable bifaces suggests high residential mobility, perhaps coincident with the development of boreal forest and a reduction in bison herds.

In Component 4 there is evidence for more early-stage reduction, including early-stage platform preparation, low frequencies of interior surface lipping, and moderate numbers of exterior flake scars. This pattern persists in Component 5, which also has the largest number of cores. Debitage is notable for a high frequency of cortical debitage, a variety of size ranges, platform preparation consistent with earlystage reduction, and moderate numbers of exterior flake scars. 
In Component 6 there are spatially discrete areas of different types of debitage. Early-stage reduction occurred at the east and west ends of the excavated area, and a small patch of late-stage debitage was associated with a hearth between these areas.

No clear patterns can be seen in the small debitage sample from Component 7. Late-stage reduction is well represented in the debitage of Component 8, mainly to the southeast of a hearth in the centre of the excavation area. In this area, interior surface lipping and exterior flake scar counts suggest late-stage reduction or tool maintenance. The presence of broken conjoinable formed artifacts also supports this interpretation. On the northern side of the main excavation, a possible cache of chert flakes was recovered. These specimens are from the same raw material, have a high frequency of cortex, and are much larger than other debitage. They display no retouch, and no other pieces of this raw material were found in this component. Component 8 therefore includes both early- and late-stage reduction debitage.

In Component 9 the combination of small debitage size, late-stage platform preparation, interior surface lipping, and moderately high numbers of exterior flake scars suggests the manufacture and maintenance of tools in an oval depression in front of the cave entrance. Other debitage suggests that earlier stages of lithic artifact production also occurred. Both of these activities continue into Component 10.

\section{FAUNAL REMAINS}

In comparison with most sites in the region, faunal preservation is good at Charlie Lake Cave. This is particularly true for the fauna from Zone II, where relatively rapid deposition resulted in excellent preservation of quite fragile bones. The vast majority of specimens are from small mammals, birds and fish, and large mammals (bison, moose, elk) are quite rare. Many specimens probably reached the site as the result of natural processes.

Work on the large collection of fauna is in progress. Driver identified the entire collection from the 1983 excavations, focusing mainly on paleoenvironmental studies (Driver, 1988, 1996; Driver and Hobson, 1992). As the 1990 and 1991 collections appeared very similar to those reported earlier, a subsample of specimens from four excavation units has been selected for further study. Preliminary results show that the range of species identified from the 1990 and 1991 samples is very similar to that identified from the 1983 collection. The most obvious faunal change occurs at the Pleistocene-Holocene boundary, where the dominant small mammal changes from ground squirrel (Spermophilus sp.) to snowshoe hare (Lepus americanus). This change appears to mark the transition to a boreal forest from a predominantly open landscape established by pioneering plant species on the barren postglacial terrain. Since this change occurred (by about 9500 B.P.), the mammalian and avian faunas have remained fairly consistent though time.
Further evidence for the open landscape proposed for Zones IIa and IIb is the identification of a single specimen of collared lemming (Dicrostonyx torquatus) recovered from Zone IIb in 1991. This species is today confined to tundra, although during the late Pleistocene it lived south of the ice sheets (Lundelius et al., 1983).

\section{RITUAL ACTIVITY}

There is evidence from the earlier components that some ritual activities may have occurred at the site. The most obvious evidence is the presence of human remains in Component 4 . The human mandible appears to have been burnt, but it is not calcined. The specimen might be the result of an incomplete cremation, but it seems more likely that it was dislodged from its original burial position, suffered some burning (either natural or cultural), and reached its final isolated position as a result of natural processes of erosion and deposition.

The two raven skeletons in Components 1 (c. 10500 B.P.) and 3 (c. 9500 B.P.) also hint at ritual activity. The earlier skeleton is more disarticulated, possibly as a result of sediment movement after deposition. The bird was definitely deposited with some soft tissue, because the tracheal rings survived. As mentioned previously, the later bird was also deposited as an articulated specimen.

Ravens are of considerable significance in the ideology of First Nations in the Northwest, and are often associated with origin myths. In many Athapaskan stories, and in the stories of other cultures, Raven appears as a trickster and is often associated with hunting. Consequently, the discovery of two relatively complete raven skeletons inevitably leads to speculation about the role humans may have played in the deposition of the birds at the site. For the raven in Component 1 , there is no evidence of human involvement in its death or deposition. There are no cut marks, no evidence that the bird was buried, and no clearly associated artifacts. On the other hand, there is neither evidence that the bird met its death by natural predation nor evidence of carnivore scavenging. There seems to be little to choose between a hypothesis of natural death and a hypothesis of human involvement. There is more evidence that the raven in Component 3 may have been deposited by people. First, there is a definite association, both spatial and stratigraphic, between the microblade core and the raven skeleton. Both occurred in a layer of limited extent which must represent a short period of sediment deposition against the parapet. There is no evidence of deliberate burial, but the configuration of the layer suggests that it was formed as sediments infilled a depression running parallel to the back wall of the parapet. Both the microblade core and the bird were deposited in that depression. The location of the microblade core close to the raven's feet also seems deliberate. While we cannot prove an association between the artifact and the bird, it seems unlikely that a complete bird skeleton and a very unusual artifact would become associated by chance. 
It is highly speculative to even assume that the raven was a bird of great significance to people living ten millenia ago. However, the widespread mythological significance of the raven suggests that the bird's behaviour may have made it the subject of human attention in many times and places. We also find it interesting that Raven is often associated with the beginning of the world, because the first human inhabitants of Charlie Lake Cave lived in a biotic environment that had developed only shortly before the people arrived at the site and must have been changing rapidly. A modern Dene story told by Blondin (1990) relates how Raven found a cold land that was uninhabited by people, but which contained a plentiful supply of game. While we would not want to imply that such stories contain "memories" of early postglacial times, it is interesting that ravens may have been of some special significance to the people who first moved into the new lands created at the end of the Pleistocene.

\section{CONCLUSIONS}

This paper has reviewed selected data from Charlie Lake Cave, emphasizing cultural chronology and the history of site formation. Other studies will be the subject of further publications. The temporal framework reported here is well supported by a sequence of radiocarbon dates demonstrating the integrity of the stratified site. Few artifacts of any sort were found at Charlie Lake Cave for any time period. Generally, stylistically distinctive artifacts are insufficient to allow one to make confident statements about the sequence of temporally diagnostic artifacts or comparisons with archaeological sequences from neighbouring regions. Following Handly (1993), we have divided the Charlie Lake Cave sequence into Early, Middle, and Late periods. The Early Period (10 500 to 9500 B.P., Components 1 to 3 ) contains a basally thinned projectile point similar to specimens known mainly from areas to the south and east, and a microblade core which has some affinities to the north. Until larger number of artifacts are recovered from other dated contexts, we cannot relate this period in any detail to cultural chronologies elsewhere. For example, other Paleoindian projectile point styles (e.g., Agate Basin, Scottsbluff) are known from surface collections in the Peace River region, but are not represented at this particular site.

The lack of occupation at the site from about 9500 to 7000 B.P. probably does not indicate a regional abandonment or depopulation. Middle and Late Prehistoric occupations differed from earlier uses of the site. The occupations were more intense, involved a greater range of activities, and resulted in the creation of excavated features and denser deposits of bone and lithics. These have been interpreted as resulting from residential activities in Middle Prehistoric times and more specialized activities in the Late Prehistoric. The stylistically distinctive artifacts from Middle and Late Prehistoric components are generally comparable to artifacts from other sites in northern British Columbia and Alberta, the Yukon, and the Northwest Territories.

\section{ACKNOWLEDGEMENTS}

During the course of the excavations we received help from many people. The 1983 and 1990 owner of the site, John Cleeve, and the 1991 owners, Rory and Troy Henderson, kindly allowed us to disturb their property and attract numbers of visitors. In 1990 the Huhn family was renting the house at the site, and they were very helpful in many ways. We are grateful to everyone who helped on the excavations, but especially to two people. Dick Gilbert is the only person who has participated in every excavation at the site, and was responsible for encouraging Fladmark to return to the site in 1983 and Driver in 1990. His hard work and friendship are appreciated. John Breffitt not only excavated in 1990, but also used his expertise to make the site a safe place to work in the next season. In Charlie Lake and Fort St. John we were welcomed and helped by many people, including Donna Kyllo of the Fort St. John Museum and many people in the North Peace Historical Society; Finola Finlay of Northern Lights College; Beth Todrick, who found us a place to live; the Dixon family, who let us use their well water; and everyone at the Charlie Lake store and post office. The first draft of this paper has been improved by the critical comments of three reviewers.

\section{REFERENCES}

AHLER, S.A. 1989. Mass analysis of flaking debris: Studying the forest rather than the tree. In: Henry, D.O., and Odell, G.H., eds. Alternative approaches to lithic analysis: Proceedings of the University of Tulsa Conference on Lithic Analysis. Tulsa, Oklahoma: University of Tulsa. 85-118.

APLAND, B., and HARINGTON, C.R. 1994. Pleistocene bison skeleton (Bison bison cf. occidentalis) from Clayhurst Crossing, British Columbia. Geographie Physique et Quaternaire 48(2):213-223.

BAUMLER, M.F., and DOWNUM, C.E. 1989. Between micro and macro: A study in the interpretation of small-sized debitage. In: Amick, D.S., and Maudlin, R.P., eds. Experiments in lithic technology. International Series No. 528. Oxford: British Archaeological Reports. 101-116.

BLONDIN, G. 1990. When the world was new. Yellowknife: Outcrop.

BOBROWSKY, P.T., and RUTTER, N. 1992. The Quaternary geologic history of the Canadian Rocky Mountains. Geographie Physique et Quaternaire 46(1):5-50.

BRINK, J., and DAWE, R.J. 1986. An introduction to the prehistory of the Grand Cache region, northern Alberta Rocky Mountains. In: Ronaghan, B., ed. Eastern slopes prehistory: Selected papers. Occasional Paper No. 30. Edmonton: Archaeological Survey of Alberta. 161-246.

BRYAN, A.L., and CONATY, G. 1975. A prehistoric Athapaskan campsite in northwestern Alberta. Western Canadian Journal of Anthropology 5(3-4):64-87.

CLARK, D.W.1992. A microblade production site (KbTx-2) in the south central Yukon. Canadian Journal of Archaeology $16: 3-23$. 
DAVIS, L.B., and GREISER, S.T. 1992. Indian Creek Paleoindians: Early occupation of the Elkhorn Mountains' southeast flank, west-central Montana. In: Stanford, D.A., and Day, J.S., eds. Ice Age hunters of the Rockies. Niwot, Colorado: University Press of Colorado. 225-283.

DONAHUE, P.F. 1975. Concerning Athapaskan prehistory in British Columbia. Western Canadian Journal of Anthropology 5(3-4):21-63.

DRIVER, J.C. 1988. Late Pleistocene and Holocene vertebrates and palaeoenvironments from Charlie Lake Cave, northeast British Columbia. Canadian Journal of Earth Sciences 25:15451553.

- 1996. The significance of the fauna from Charlie Lake Cave. In: Carlson, R.L., and Dalla Bona, L., eds. Early human occupation in British Columbia. Vancouver: University of British Columbia Press. 21-28.

DRIVER, J.C., and HOBSON, K.A. 1992. A 10 500-year sequence of bird remains from the southern boreal forest region of western Canada. Arctic 45(2):105-110.

FEDJE, D.W., WHITE, J.M., WILSON, M.C., NELSON, D.E., VOGEL, J.S., and SOUTHON, J.R. 1995. Vermilion Lakes site: Adaptations and environments in the Canadian Rockies during the latest Pleistocene and early Holocene. American Antiquity 60(1):81-108.

FLADMARK, K.R. 1975. Peace past: A report on the archaeological reconnaissance of the Peace River basin, 1974 field season. Report submitted to Archaeological Sites Advisory Board (Victoria) and B.C. Hydro. Report on file, Archaeology Branch, Victoria, British Columbia V8V 1X4, Canada.

. 1996. The prehistory of Charlie Lake Cave. In: Carlson, R.L., and Dalla Bona, L., eds. Early human occupation in British Columbia. Vancouver: University of British Columbia Press. 11-20.

FLADMARK, K.R., DRIVER, J.C., and ALEXANDER, D. 1988. The Palaeoindian component at Charlie Lake Cave (HbRf-39), British Columbia. American Antiquity 53(2):371-384.

FRISON, G.C. 1991. The Goshen Paleoindian complex: New data for Paleoindian research. In: Bonnichsen, R., and Turnmire, K.L., eds. Clovis: Origins and adaptations. Corvallis, Oregon: Center for the Study of the First Americans. 133-151.

GRYBA, E.M. 1983. Sibbald Creek: 11,000 years of human use of the Alberta foothills. Occasional Paper 22. Edmonton: Archaeological Survey of Alberta.

HANDLY, M.J. 1993. Lithic assemblage variability at Charlie Lake Cave (HbRf-39): A stratified rockshelter in northeastern British Columbia. Unpubl. M.A. thesis, Department of Anthropology, Trent University, Peterborough, Ontario.

LEBLANC, R.J., and IVES, J.W. 1986. The Bezya site: A wedgeshaped core assemblage from northeastern Alberta. Canadian Journal of Archaeology 10:59-98.

LICHTI-FEDEROVICH, S.1970. The pollen stratigraphy of a dated section of late Pleistocene lake sediment from central Alberta. Canadian Journal of Earth Sciences 7(3):938-945.

LUNDELIUS, E.L., GRAHAM, R.W., ANDERSON, E., GUILDAY, J., HOLMAN, J.A., STEADMAN, D.W., and WEBB, D.S. 1983. Terrestrial vertebrate faunas. In: Porter, S.C., ed. Late-Quaternary environments of the United States,
Vol. 1, The Late Pleistocene. Minneapolis: University of Minnesota Press. 311-353.

MacNEISH, R.S. 1960. The Callison site in the light of archaeological survey of SW Yukon. In: Contributions to Anthropology 1957. National Museum of Canada Bulletin No. 162, Anthropological Series No. 45. Ottawa: Department of Northern Affairs and Natural Resources.

MATHEWS, W.H. 1980. Retreat of the last ice sheets in northeastern British Columbia and adjacent Alberta. Bulletin 331. Ottawa: Geological Survey of Canada.

MILLAR, J.F.V. 1968. Archaeology of Fisherman Lake, western District of Mackenzie, N.W.T. Unpubl. Ph.D. dissertation, Department of Archaeology, University of Calgary, Calgary, Alberta.

MOBLEY, C.M. 1991. The Campus Site. Fairbanks: University of Alaska Press.

MORRISON, D.A. 1987. The middle prehistoric period and the archaic concept in the Mackenzie valley. Canadian Journal of Archaeology 11:49-74.

NOBLE, W.C. 1971. Archaeological surveys and sequences in central District of Mackenzie, N.W.T. Arctic Anthropology 8(1):102-135.

POWERS, W.R., and HOFFECKER, J.F. 1989. Late Pleistocene settlement in the Nenana Valley, central Alaska. American Antiquity 54(2):263-287.

PYSZCZYK, H.W. 1991. A wedge-shaped microblade core, Fort Vermilion, Alberta. In: Magne, M., ed. Archaeology in Alberta 1988 and 1989. Occasional Paper 33. Edmonton: Archaeological Survey, Provincial Museum of Alberta. 199-204.

RICHARDS, T.H., and ROUSSEAU, M.K. 1987. Late prehistoric cultural horizons on the Canadian Plateau. Publication 16. Burnaby: Department of Archaeology, Simon Fraser University.

ROZEN, K.C., and SULLIVAN, A.P. 1989. Measurement, method, and meaning in lithic analysis: Problems with Amick's and Mauldin's middle-range approach. American Antiquity 54(1):169-175.

SANGER, D. 1968. The High River microblade industry. Plains Anthropologist 13(41):190-208.

SPURLING, B.E. 1980. The Site C heritage resource inventory and assessment final report. Report submitted to British Columbia Hydro and Power Authority. Report on file, Archaeology Branch, Victoria, British Columbia V8V 1X4, Canada.

SPURLING, B.E., and BALL, B.F.1981. On some distributions of the Oxbow "complex." Canadian Journal of Archaeology 5:89102.

THOMSON, H.R. 1973. An introduction to the prehistory of the Peace River country. Unpubl. M.A. thesis, Department of Anthropology, University of Alberta, Edmonton, Alberta.

WILMSEN, E.N. 1970. Lithic analysis and cultural inference: A Paleo-Indian case study. Anthropological Papers of the University of Arizona, No. 16. Tucson: University of Arizona Press.

WORKMAN, W.B. 1978. Prehistory of the Aishihik-Kluane area, southwest Yukon Territory. Mercury Series, Archaeological Survey of Canada Paper No. 74. Ottawa: National Museum of Man. 